\title{
The healthy concern to improve neurological teachings
}

\author{
A saudável preocupação em melhorar o ensino da neurologia \\ Péricles Maranhão-Filho
}

Departamento de Neurologia, Faculdade de Medicina,

Universidade Federal do Rio de Janeiro, Rio de Janeiro RJ, Brazil.

\section{Correspondence:}

Péricles Maranhão-Filho;

Av. Prefeito Dulcídio Cardoso, 1680/

1802; 22620-311 Rio de Janeiro RJ;

Brasil; E-mail: pmaranhaofilho@ gmail.com

Conflict of interest:

There is no conflict of interest to declare.

Received 17 August 2014

Accepted 16 September 2014

raditionally, the purpose of undergraduate education at virtually all medical
schools has been to prepare students to enter practice immediately after
graduation ${ }^{1}$.
The quality of medical teachings has been long discussed. In 1913 William Osler wrote: "In every department of human knowledge men are asking guidance in the solution of a world-old problem - how to train the mind and the heart of the young". Already at that time Osler recommended simplifying the medical curriculum to give students more time to study and also emphasized the important role of teachers in helping students to observe and reason $^{2}$. A major problem in medical education today is the lack of integration of basic science and clinical information into a cohesive whole. If either of these is taught in a vacuum, the medical student frequently is unable to reason through clinical problems, and this can result in anxiety, dislike, and eventual disinterest in the subject matter. These negative sentiments are applicable to the study of neurology in medical schools. Students perceive that the neural sciences and clinical neurology are overly complex, and many of them develop a fear of the neural sciences and clinical neurology due the inability to apply their knowledge of basic sciences to clinical situations, creating a "neurophobia syndrome" ${ }^{\text {. }}$

In our country, the Brazilian Academy of Neurology requested a survey that compared the panorama of neurology teaching in Brazil with that in other countries. The results of this well-prepared study were presented exactly a half century ago, at the first Brazilian Academy of Neurology Congress, and this document, alongside other recommendations stressed the importance of integrating clinical neurological education with neuroanatomy, neurophysiology, and the fundamentals of neuropathology ${ }^{4}$. Aspects that remains fully valid until today.

Reflection and critique of teaching techniques are vital to propel medical schools towards promoting and aiming for excellence in medical education ${ }^{5}$. There needs to be a debate on whether major changes are needed in the way neuroscience and neurology are taught to medical students, to make the subject more accessible and more users friendly ${ }^{6}$.

Along the last several decades, many new models of medicine curriculums have been created. The problem-based learning curriculum (PBLC) for example, adopted at McMaster University, Canada, in $1969^{7}$, although costly has grown in popularity and spread to many parts of the world, reaching as far as Hong Kong.

In this issue of Arquivos de Neuropsiquiatria, Magalhães et al. ${ }^{9}$, concerned about the neurological teaching in Brazil, publish the article "A Brazilian original pedagogical approach to the teaching of neurology," in which they discuss survey results from students and teachers to compare his method of teaching neurology, Clinical Decision/Diagnostic Workshop (CD/DW), to traditional undergraduate teaching methods (lectures, seminars and traditional case-discussions). The authors highlight the needlessness to change curriculums, the low cost of the method implementation, and, primarily, the respect for the individual students' learning needs and tempo, besides prioritization of the teaching of diagnostic abilities from minor symptoms. They consider that motivation is the main limiting factor for implementing his program, meanwhile correctly pointing out that motivation is necessary for implementation of any other innovative teaching method. 
Offering a good medical education is knowingly a complex process that depends of many things, including money, but which is always hostage to the method / teacher binomial. A good neurological teaching method that is attractive, dynamic, and captivating to the student is exceedingly important, but one can never forget the teacher's role ${ }^{6}$. As an example, a survey was performed in seven major medical specialties among British medical students, senior house officers, and general practitioners. They were asked why they felt neurology was perceived to be such a difficult subject. The 70 people who answered questions gave eighty-one reasons, of which the most common was "poor teaching". This survey confirms just how difficult neurology is perceived to be, not only by students but also by senior house officers and general practitioners.

The teacher's main job is to equip students with an enthusiasm to learn. Good teachers inspire, entertain, and support their students in their learning. They encourage the student to actively acquire knowledge learning through problem solving rather than passively absorb information.
Considering the extremely competitive selection process for undergraduate medical student slots in Brazil ${ }^{10}$, teachers are privileged to have students who are, at least theoretically, among the most intelligent and highly motivated in the country; so a failure for them to learn must be more closely associated to the teachers, and not the students ${ }^{11}$.

In the university where I teach, we apply the regular theoretical course of neurology for students in the sixth semester. Our classes still use traditional methods. The students consistently consider the course "one of the best courses throughout medical school" in their class evaluations. Nevertheless, we unfortunately have few quality control processes in place, and performance feedback beyond the sixth semester is seldom given. A curriculum change is in course and scheduled to be implemented within the next two years.

The issue in question is not one that can be resolved quickly. Only time will tell whether the methods presented here by Magalhães et al. ${ }^{9}$ can be a tool that will allow that the very common "neurophobia syndrome" to become a "neurophilia syndrome"12.

\section{References}

1. Menken M., Sheps CG. Undergraduate education in the medical specialties: the case of neurology. N Engl J Med. 1984;311(16):1045-8. http://dx.doi.org/10.1056/NEJM198410183111610

2. Osler W. An introductory address on examinations, examiners, and examinees. Lancet. 1913;2:1047-50.

3. Jozefowicz RF. Neurophobia: the fear of neurologyamong medical students. Arch Neurol. 1994;51(4):328-3. http://dx.doi.org/10.1001/ archneur.1994.00540160018003

4. Pupo PP, Armbrust-Figueiredo J. Ensino da neurologia. Arq Neuropsiquiatr. 1965;23:205-19.

5. Ramani S. Twelve tips to promote excellence in medical teaching. Med Teach. 2006;28(1):19-23. http://dx.doi.org/10.1080/01421590500441786

6. Schon F, Hart P, Fernandez C. Is clinical neurology really so difficult? [Editorial]. J Neurol Neuros Psych. 2002;72(5):557-9. http://dx.doi. org/10.1136/jnnp.72.5.557

7. Neufeld VR, Woodward CA, MacLeod SM. The McMaster M.D. programme: a case study of renewal in medical education. Acad Med. 1989;64:423-32.
8. Nandi PL, Chan JNF, Chan CPK, Chan P, Chan LPK. Undergraduate medical education: comparison of problem-based learning and conventional teaching. Hong Kong Med J. 2000;6(3):301-6.

9. Magalhães LVB, Fernandes PT, Magalhães DSF, Bastos RR, Min LL. A Brazilian original pedagogical approach to the teaching of neurology Arq Neuropsiquiatr. 2014;72:747-52.

10. FUVEST. Relação candidato vaga inscritos. São Paulo: FUVEST; 2014 [acesso em 14 ago 2014]. Disponivel em: http://download. uol.com.br/vestibular2/concorrencia/usp_relacao_candidato_vaga_2013. pdf

11. Allen C. Teaching clinical neurology. Pract Neurol. 2012;12(2):97-102. http://dx.doi.org/10.1136/practneurol-2011-000196

12. Fuller GN. Neurophilia: a fascination for neurology: a new syndrome. Pract Neurol. 2012;12(5):276-8. http://dx.doi.org/10.1136/practneurol2012-000400 